\title{
Faculty Members Conceiving and Practicing Their Roles in the Planning, Implementation and Assessment of University Courses
}

\author{
Dr. Ahmed Rabee \\ Educational Administration \\ Jerash University \\ Prof. Shaher Dheeb Abu Shreikh \\ Curricula and Teaching \\ Jerash University
}

\begin{abstract}
This study aims at exploring how faculty members conceive their own roles in planning, implementing and assessing university courses and to what extent the same is related to their teaching practices from their students' perspectives. Upon a correlatively descriptive approach, the survey includes 123 faculty members and 385 students at Jerash University, Jordan, in the first semester of 2017/2018. The total degree of the planning role conceived is moderate with a mean of 3.39 but it is high as to both the implementation and assessment ones with means of 3.49 and 3.92 respectively. For the degrees of practicing the same roles, they are all moderate according to the sample students with means of 2.19, 2.26 and 2.03 respectively. Finally, the correlation between the faculty members' conceptions of their roles in the planning, implementation and assessment of university courses on the one hand, and their teaching practices according to the students on the other hand were all moderate and statistically significant.
\end{abstract}

Keywords: Faculty members; planning, implementation and assessment; teaching practices.

\section{Introduction}

University teaching has been a considerable pillar of education at its various stages. It is a growing, collective process for preparing future leaders and developing a well-built society with an academically guided set of values and thoughts. A university teacher (thereafter, a faculty member) helps organize the value system, improve societal behaviors and give skills, knowledge and experiences for a more prosperous future. As one of the most esteemed careers in the world, university teaching has been a blend of leadership, criticism and direction; furthermore, it is an effective combination of both qualification and experience with a highly vital role for a faculty member in education.

In this respect, teaching skills constitute a basic part of the educational process. They are known as "the actions and practices that reflect a set of abilities necessary for administering a classroom situation" (Suleiman and Essa, 2006: p. 443). According to Zaitoun (2004), a teaching practice is also "a set of skills, knowledge and attitudes necessary for successful teaching" (p. 9); it is related to the procedural side of teaching-inside and outside the classroom, including the teacher's actions and his/her students' amount of interaction (Ashoush, 2015: p. 13). A successful teaching process is attributed to the teacher's mastery of proper skills (Qandil, 2010) on both sides of thought and conduct. Such teaching skills are three: planning, implementation and assessment.

Planning as the first skill a faculty member takes on can be defined as "a process that entails a mental conception of an educational situation prepared by the teacher to achieve certain goals, and this includes the definition of such goals and selection of actions, techniques, dimensions and facilities to have them both achieved and assessed" (Tartouri and Qudhat, 2006: p. 23). Generally speaking, to plan for a teaching course is an approach or an organized method of work. For university courses in particular, planning is the wise vision of a faculty member, in which all the aspects and pillars of an educational process are rightly interrelated for attaining effective outputs and, hence, developing the students intellectually, physically and sentimentally (Fahmi, 2011). In this respect, the basic role of a faculty member is to: 
- have his/her teaching courses well-planned,

- provide proper counseling to help the students re-explore and make use of the facts of knowledge,

- make sure of the availability of all the audiovisuals that can be used in the classroom,

- develop the students' cognitive operations and improve their emotional reactions,

- strengthen the students' dynamic and physical skills in a balanced manner,

- train the students on the theoretical and practical aspects of thinking and experimenting, and

- enable the techniques of purposeful discussion and possess proper skills of communication.

As regards the second skill, Doyle (2008) defines implementation as "an educational activity corrected as per specific criteria and can be divided into cognitive or skill-related levels" (p. 168). To implement is "a set of criteria for planning a teaching task, setting its goals, describing and defining the actions necessary for implementing it and distributing the roles of implementation between the teacher and his/her students" (Herman, 2003, 198; Jackson, 2009, 112). In actual fact, the educational environment plus the emotional and social interaction inside the classroom help the students love learning, cooperate and cope with their roles; they would certainly accept their teacher as a counselor or organizer of their teaching process (cf. Tartouri, 2006) and as a positive administrator of any potential events or crises (Arabiyyat, 2007).

The last teaching skill is assessment. To assess is "to judge something or give it a value; it is an official, systematic effort as to an educational phenomenon" (Dosari, 2009: p. 34) or "to certain persons or thoughts" (Salam, 2005: p. 16). In a related respect, Ghubeisi (2010) defines it "an organized process to collect data and interpret things so as to make judgments on students or programs, help direct the educational work and take appropriate actions" (p. 29). For a faculty member, assessing is an ongoing process via such tools as questions, exercises, exams, interviews and observations. Each tool has its own features; generally, assessment makes a teacher as a learning facilitator instead of being only a transferor of knowledge according to which his/her students are responsible for their learning by self-made assessment (Khalili, 2009: p. 118). A successful teaching course or program should always be accompanied by an assessment process from its being planned to being implemented.

In light of this background, several calls have recently emerged for reforming higher education. However, most of this reform is to focus on the university teacher him/herself although it is a total process to cover all aspects. To develop an educational system is necessarily to keep your mind on the teacher for his/her distinct status as a real source of influence in any reform. Therefore, the present study is significant in providing an investigation of the teaching roles and practices taken on by university teachers. The attention of the persons in charge is also attracted to the university teachers' important role in a) adding to the higher-education mission and b) leading the coming generations and building up an upright society. It is to answer the following three research questions:

1- How do the faculty members conceive their roles in planning, implementing and assessing their university courses?

2- What teaching practices do the faculty members at Jerash University really take on according to their students?

3- To what extent are the faculty members' conceptions of the three roles related to their teaching practices?

\section{Literature review}

Having read through the related literature, the present study is found to be in agreement with a number of previous studies. This kind of agreement is almost methodical in terms of the analytical descriptive approach and the population of faculty members and also goal-oriented in terms of the teaching skills:

- A study by Suzanne \& Dale (1999) aimed at exploring the factors behind the efficiency of a faculty member and defining the problems he/she would encounter. Two considerable problems were encountered: the difficulty to organize the terms of a teaching course and the employment of traditional teaching techniques.

- Mujeidil (1999) also defined and attempted to solve the academic problems faced up by a sample of 400 faculty members at Damascus University. The increased numbers of students, unavailability of modern teaching techniques, dependence almost on traditional exams and restriction to the textbook(s) with no reference to any other sources were the most remarkable problems.

- Tackling the features of model teaching from the perspective of 708 faculty members in Australian universities, Ballantyne et al. (1999) stressed that the limited background in educational fundamentals was a real problem, the matter which would cause more traditional teaching plans and teachniques. 
- In a related respect, Ghafour (2002) addressed the problems that a faculty member would face and might affect his/her job performance at the College of Basic Education in Kuwait. Among the problems found by this study were the unequipped classrooms in terms of teaching aids, airconditioning, lightening and cleaning services and availability of necessary references.

- Filmban (2002) also addressed the patterns and solutions of any obstacles that might affect a faculty member's performance. A set of such obstacles were defined to be: a) academic such as the teacher's poor knowledge and mother and/or foreign language inproficiency, or b) intellectual such as his/her ideological attitude(s), poor achievemnt in research, increased load for many teaching courses and working hours and being inaccountable for low performance.

- Aiming to explore the relationship between a faculty member's teaching practices and personal variables, Aswad (2014) was a correlatively descriptive study whose research sample was randomly selected from four universities: Al Wadi University, Warqela University, Gradya University and Al Aghwat University. Lower performance was found vis-à-vis the total level of proficiency already set to be $75 \%$ at all the dimensions of the given innovative practices.

In conclusion, the present study is different from previous studies as it addresses the relationship between faculty members conceiving and practicing their roles in the planning, implmenetion and assessment of university courses. Procedurally, a university teacher defined for the purpose of this study is a person that holds a Ph.D. degree, being an assistant professor and above and teaching at Jerash University in Semester 1 of 2017/2018. Also, the teaching practices are all the educational activities, behavioral patterns and mental, verbal and emotional responses made by a faculty member at Jerash University inside the classroom to convey to his/her students the concepts, terms and thoughts included in a teaching course.

\section{Research method}

A correlatively descriptive approach was adopted by the present study. It is one of "the research approaches by which one can realize whether there is a relationship between two or more variables" (Assaf, 2012: 29). The population of the study is all the faculty members at Jerash University in Jordan amounting to 166, along with a number of 3450 students for 2017/2018. However, the research sample was represented by only 123 university teachers and 385 students. For the tool(s) and actions of the study, they were as follows:

- A survey was developed on the faculty members' conceptions of their role in any of the following aspects of courses:

1. planning (7 statements),

2. implementation (19 statements) and

3. assessment (5 statements).

- Moreover, the survey included 18 positive statements and another 13 negative ones.

- The responses were identified by a five-point scale (i.e. strongly agree, agree, uncertain, disagree and strongly disagree) given numbers 5-4-3-2-1 for the positive statements and 1-2-3-4-5 for the negative ones.

For the survey's psychometric properties, it was given to a number of experts and specialists in higher education, curricula and assessment, educational management and educational psychology for verifying its validity. This action aimed at validating the instrument's appropriateness to the purpose it had been designed for and receiving any opinions on the clearness of its statements suggesting any addition, omission or alteration. The experts' suggestions were actually taken into account. For verifying the survey's internal consistency, the correlation coefficients were computed for each aspect as well as the total degree of the same-being positive, high and statistically significant at 0.01 - to be eventually as follows: planning $(=0.78)$, implementation $(=0.89)$ and assessment $(=0.77)$.

As regards the reliability of the study's instrument, it was administered to another sample of the same population to include 35 faculty members and 62 male/female students. Using the Cronbach's alpha coefficient, the results for the faculty members were as follows: planning $(=0.76)$, implementation $(=0.79)$ and assessment $(=0.74)$, and for the students were as follows: planning $(=0.85)$, implementation $(=0.87)$ and assessment $(=0.82)$. Furthermore, the datasets were analyzed by the Statistical Package for the Social Sciences (SPSS) based on the following techniques: 
- Pearson correlation coefficient for making certain of the internal reliability of the survey and its various dimensions.

- Cronbach's alpha coefficient for making certain of the validity of the study's instrument.

- Means and standard deviations (SDs) for exploring how highly the faculty members conceive their roles in any of the aforesaid aspects.

- One sample T-test for identifying how the variables of the study's respondents are different.

- Pearson Correlation for examining the correlation between the faculty members' conceptions of their roles and their teaching practices.

- The study was based on the following criteria:

1. Criteria to judge the faculty members conceiving their roles in planning, implementing and assessing university courses from their own perspectives:
Mean:
Less than 1.8
Conceiving degree:
$1.8-2.6$
Very low
$2.6-3.4$
Low
$3.4-4.2$
Moderate
4.2 above
High
Very high

2. Criteria to judge the faculty members practicing their roles in planning, implementing and assessing the courses from their students' perspectives:
Mean:
Less than 1.67
Practicing degree:
$1.67-2.34$
Low
2.34 above
Moderate
High

\section{Results and discussion}

First: For answering the first research question of the study (i.e. how do the faculty members conceive their roles in planning, implementing and assessing their university courses?), the means and SDs were computed for the total degree of how the faculty members at Jerash University conceive their roles in planning, implementing and assessing their teaching courses from their own perspectives. The results were as follows (see Tables 1, 2 and 3):

\section{Planning}

Table (1) Means and SDs of the Faculty Members Conceiving their Planning Role

\begin{tabular}{|c|l|l|l|l|l|}
\hline Sr. & Statements & & & & (n) \\
\hline 1 & $\begin{array}{l}\text { Successful teaching requires that the desired } \\
\text { output(s) of a teaching course is identified earlier. }\end{array}$ & 4.62 & 0.70 & $\begin{array}{l}\text { Very } \\
\text { high }\end{array}$ & 1 \\
\hline 2 & $\begin{array}{l}\text { To envision the accurate wording of a lesson's } \\
\text { goals is not important for a teaching course. }\end{array}$ & 3.22 & 1.42 & Moderate & 3 \\
\hline 3 & $\begin{array}{l}\text { To distribute the educational outputs to the mental, } \\
\text { cognitive and emotional aspects is not important in } \\
\text { a teaching course. }\end{array}$ \\
\hline 4 & $\begin{array}{l}\text { Planning in teaching courses is not only restricted } \\
\text { to the teaching strategies. }\end{array}$ & 2.80 & 1.40 & Moderate & 6 \\
\hline 5 & $\begin{array}{l}\text { Planning in teaching courses is not important to all } \\
\text { student levels. }\end{array}$ & 3.20 & 1.35 & Moderate & 4 \\
\hline 6 & $\begin{array}{l}\text { The electronic availability of knowledge is proper } \\
\text { enough to replace previous planning. }\end{array}$ & 3.03 & 1.35 & Moderate & 5 \\
\hline 7 & $\begin{array}{l}\text { The effort exerted in planning a teaching course is } \\
\text { not that much beneficial. }\end{array}$ & 3.96 & 1.12 & High & 2 \\
\hline Total & 3.39 & 1.25 & Moderate & - \\
\hline
\end{tabular}


As illustrated by Table (1) above, the faculty members' role in planning their teaching courses was moderate with a total mean of $3.39(\mathrm{SD}=1.25)$. The responses on the planning-related statements were almost harmonious. University teaching is not to mainly depend on a planning role restricted by specific strategies or textbooks; it is however free of rules. The highest statement was no. 1 "Successful teaching requires that the desired output(s) of a teaching course is identified earlier" with a mean of $4.62(\mathrm{SD}=0.70)$ and a very high conceiving degree. This finding reflects how largely a faculty member in preparing for his/her lectures adheres to certain outcomes at the end.

\section{Implementation}

Table (2) Means and SDs of the Faculty Members Conceiving their Implementation Role

\begin{tabular}{|c|c|c|c|c|c|}
\hline Sr. & Statements & $\sum_{\tilde{E}}^{\tilde{E}}$ & \% & 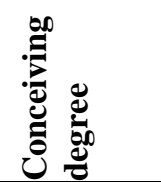 & 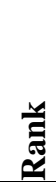 \\
\hline 1 & $\begin{array}{l}\text { Structural and consecutive actions to implement a lesson } \\
\text { are not related to the preparation to it. }\end{array}$ & 3.27 & 1.07 & Moderate & 16 \\
\hline 2 & $\begin{array}{l}\text { The ideal usage of technology in implementing a lesson } \\
\text { enriches it. }\end{array}$ & 3.60 & 1.14 & High & 13 \\
\hline 3 & $\begin{array}{l}\text { A student's weak achievement is generally the most } \\
\text { considerable mistake of implementation. }\end{array}$ & 3.44 & 1.25 & High & 14 \\
\hline 4 & $\begin{array}{l}\text { Suitable preparation for a lesson is the first step to } \\
\text { implement it. }\end{array}$ & 4.61 & 0.65 & Very high & 1 \\
\hline 5 & $\begin{array}{l}\text { Excessive care of educational technologies might cause } \\
\text { late implementation in teaching the given course. }\end{array}$ & 2.75 & 1.31 & Moderate & 19 \\
\hline 6 & $\begin{array}{l}\text { The various actions in implementing a lesson cause } \\
\text { enrichment and motivation with the learners. }\end{array}$ & 4.37 & 0.76 & Very high & 6 \\
\hline 7 & $\begin{array}{l}\text { The audible and motional effects of a university teacher } \\
\text { cause the successful implementation of a course. }\end{array}$ & 4.10 & 1.06 & High & 10 \\
\hline 8 & $\begin{array}{l}\text { Classroom interaction enlarges the effective } \\
\text { implementation of teaching a course. }\end{array}$ & 4.38 & 0.91 & Very high & 4 \\
\hline 9 & $\begin{array}{l}\text { The quantitative content of a teaching course does not } \\
\text { negatively affect its being implemented. }\end{array}$ & 3.23 & 1.11 & Moderate & 17 \\
\hline 10 & $\begin{array}{l}\text { The educational environment has a direct influence on } \\
\text { the implementation of a teaching course. }\end{array}$ & 4.30 & 0.70 & Very high & 8 \\
\hline 11 & $\begin{array}{l}\text { The variation of enhancement techniques is required for } \\
\text { the successful implementation of a course. }\end{array}$ & 4.37 & 0.71 & Very high & 5 \\
\hline 12 & $\begin{array}{l}\text { Terms and ideas included in a teaching course help } \\
\text { effectively implement the lesson. }\end{array}$ & 4.20 & 0.94 & Very high & 9 \\
\hline 13 & $\begin{array}{l}\text { To depart from the main topic of a lesson wastes the } \\
\text { time devoted for implementation. }\end{array}$ & 3.69 & 1.26 & High & 12 \\
\hline 14 & $\begin{array}{l}\text { The insisted variation of learning resources enlarges the } \\
\text { effective implementation of a teaching course. }\end{array}$ & 4.03 & 0.91 & High & 11 \\
\hline 15 & $\begin{array}{l}\text { The controlled time of a lecture is a must to implement } \\
\text { the terms of a teaching course. }\end{array}$ & 4.34 & 0.70 & Very high & 3 \\
\hline 16 & $\begin{array}{l}\text { The topics included in a teaching course are employed } \\
\text { to the everyday life skills. }\end{array}$ & 4.57 & 0.61 & Very high & 2 \\
\hline 17 & $\begin{array}{l}\text { The teacher's feeling of mastering the topics of a } \\
\text { teaching course attracts the students to learn. }\end{array}$ & 4.30 & 0.82 & Very high & 7 \\
\hline 18 & $\begin{array}{l}\text { A course cares of the individual differences that help the } \\
\text { teacher have effective actions in teaching. }\end{array}$ & 3.27 & 1.30 & Moderate & 15 \\
\hline 19 & $\begin{array}{l}\text { The teaching course's topics are a key factor to attract } \\
\text { and motive the students to learn. }\end{array}$ & 3.20 & 1.26 & Moderate & 18 \\
\hline \multicolumn{2}{|r|}{ Total } & 3.94 & 0.95 & High & - \\
\hline
\end{tabular}

With a mean of $3.94(\mathrm{SD}=0.95)$ as per Table (2) above, the total degree as to the faculty members conceiving their role in implementing their teaching courses was high. The University was found to be concerned with holding workshops on an ongoing basis helping the faculty members be more familiar with any developments in 
university teaching, the matter which turns this particular role to be a priority or ambition of theirs. The highest statement was no. 4 "Suitable preparation for a lesson is the first step to implement it" with a mean of 4.67 $(\mathrm{SD}=0.65)$, which reflects that a faculty member insists on initially directing or motivating his/her students toward the topic of a new lesson and, then, helping them smoothly move from a preceding subject to a newer one.

\section{Assessment}

Table (3) Means and SDs of the Faculty Members Conceiving their Assessment Role

\begin{tabular}{|c|c|c|c|c|c|}
\hline Sr. & Statements & $\sum_{\Sigma}^{\Xi}$ & क & 荬 & 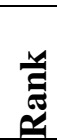 \\
\hline 1 & $\begin{array}{l}\text { Structural assessment helps the teacher go flexibly } \\
\text { with the course's exercises. }\end{array}$ & 3.38 & 0.92 & Medium & 4 \\
\hline 2 & $\begin{array}{l}\text { Final assessment is a kind of feedback for the } \\
\text { teacher to address the strengths and weaknesses in } \\
\text { a teaching course. }\end{array}$ & 4.36 & 0.79 & $\begin{array}{l}\text { Very } \\
\text { high }\end{array}$ & 1 \\
\hline 3 & $\begin{array}{l}\text { Personal assessment helps choose a suitable type of } \\
\text { courses to the student. }\end{array}$ & 3.24 & 1.10 & Moderate & 5 \\
\hline 4 & $\begin{array}{l}\text { The various strategies of assessment enrich a } \\
\text { teaching course. }\end{array}$ & 4.07 & 1.04 & High & 2 \\
\hline 5 & $\begin{array}{l}\text { Indirect assessment enhances the status of a } \\
\text { teaching course with the students. }\end{array}$ & 4.11 & 1.02 & High & 3 \\
\hline Tota & & 3.92 & 0.92 & High & - \\
\hline
\end{tabular}

Reflecting the faculty members' concern in improving and developing the educational process by focusing on multiple assessment strategies, Table (3) above shows a high degree as to their own role in assessing their teaching courses with a mean of 3.92 ( $\mathrm{SD}=0.92$ ). The highest statement in this respect was no. 2 "Final assessment is a kind of feedback for the teacher to address the strengths and weaknesses in a teaching course" with a mean of $4.36(\mathrm{SD}=0.79)$, revealing how effectively a faculty member directs his/her students after they know their results of achievement and motivating them toward more learning by handling their weaknesses and enhancing the strengths.

Second: For answering the second research question of the study (i.e. what teaching practices do the faculty members at Jerash University really take on according to their students?), the means and SDs were computed for the total degree of how the faculty members at Jerash University practice their roles in planning, implementing and assessing their teaching courses from the students' perspectives. The results were as follows (see Tables 1, 2 and 3):

\section{Planning}

Table (4): Means and SDs of the Faculty Members Practicing their Planning Role

\begin{tabular}{|c|c|c|c|c|c|}
\hline Sr. & Statements & $\stackrel{\Xi}{\tilde{\Xi}}$ & ค & 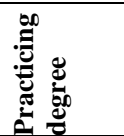 & 层 \\
\hline 1 & $\begin{array}{l}\text { The teacher discloses the outcomes desired to attain in a teaching } \\
\text { course. }\end{array}$ & 2.42 & 0.65 & High & 1 \\
\hline 2 & $\begin{array}{l}\text { The main goals of a lesson in a teaching course are not important for } \\
\text { the teacher. }\end{array}$ & 2.31 & 0.70 & Moderate & 2 \\
\hline 3 & $\begin{array}{l}\text { The distribution of the educational outputs to mental, cognitive and } \\
\text { emotional aspects is not important for the teacher when organizing the } \\
\text { course's plan. }\end{array}$ & 2.10 & 0.71 & Moderate & 7 \\
\hline 4 & $\begin{array}{l}\text { The teacher's plan of the course is not limited to the teaching } \\
\text { strategies. }\end{array}$ & 2.22 & 0.59 & Moderate & 4 \\
\hline 5 & $\begin{array}{l}\text { The teacher's plan of the course does not take into account the } \\
\text { different levels of the students. }\end{array}$ & 2.36 & 0.55 & Moderate & 3 \\
\hline 6 & $\begin{array}{l}\text { The teacher only electronically provides his/her students with terms of } \\
\text { knowledge instead of organizing them in the course plan. }\end{array}$ & 2.08 & 0.69 & Moderate & 6 \\
\hline 7 & $\begin{array}{l}\text { The teacher believes that planning a teaching course is not of an } \\
\text { educational benefit. }\end{array}$ & 2.20 & 0.69 & Moderate & 5 \\
\hline \multicolumn{2}{|c|}{ Total } & 2.19 & 0.67 & Moderate & - \\
\hline
\end{tabular}


The total degree of the faculty members practicing their role in planning a university course from their students' perspectives was moderate according to Table (4) above with a mean of 2.19 ( $\mathrm{SD}=0.67)$. In line with Ghafour (2002), this finding reflects that a faculty member's teaching load would weaken his/her concern in this regard due to the much time and effort needed for realizing the students' cognitive and academic levels and managing the prerequisite courses, suitable references and necessary teaching aids or apparatuses. The highest statement was no. 1 "The teacher discloses the outcomes desired to attain in a teaching course" with a mean of $2.42(\mathrm{SD}=0.65)$. A faculty member would like to make known such potential outcomes for helping draw up a road map to achieve the given lesson's objectives and make best use of the students' performance by minimizing any random steps or actions in teaching.

\section{Implementation}

Table (5): Means and SDs of the Faculty Members Practicing their Implementation Role

\begin{tabular}{|c|c|c|c|c|c|}
\hline Sr. & Statements & $\sum_{\tilde{E}}^{\Xi}$ & क & لَّ & $\underset{\tilde{E}}{\mathscr{E}}$ \\
\hline 1 & $\begin{array}{l}\text { Structural and consecutive actions to implement a lesson } \\
\text { are not related to the preparation for it. }\end{array}$ & 2.30 & 0.59 & Moderate & 7 \\
\hline 2 & $\begin{array}{l}\text { The teacher employs the terms and ideas belonging to a } \\
\text { teaching course for effectively implementing the lesson. }\end{array}$ & 2.95 & 0.81 & High & 1 \\
\hline 3 & $\begin{array}{l}\text { A student's weak achievement is generally the most } \\
\text { considerable mistake of implementation. }\end{array}$ & 2.39 & 0.60 & High & 5 \\
\hline 4 & $\begin{array}{l}\text { Suitable preparation for a lesson is the first step to } \\
\text { implement it. }\end{array}$ & 2.28 & 0.74 & Moderate & 8 \\
\hline 5 & $\begin{array}{l}\text { Excessive care of educational technologies might delay } \\
\text { the implementation of a teaching course. }\end{array}$ & 2.43 & 0.65 & High & 3 \\
\hline 6 & $\begin{array}{l}\text { The teacher has various actions in implementing a } \\
\text { lesson for motivating the learners. }\end{array}$ & 2.25 & 0.68 & Moderate & 13 \\
\hline 7 & $\begin{array}{l}\text { The teacher uses audible and motional effects to } \\
\text { successfully implement the course. }\end{array}$ & 2.34 & 0.71 & Moderate & 9 \\
\hline 8 & $\begin{array}{l}\text { The teacher insists on classroom interaction to enlarge } \\
\text { the effective implementation of a course. }\end{array}$ & 2.24 & 0.69 & Moderate & 10 \\
\hline 9 & $\begin{array}{l}\text { The quantitative content of a teaching course does not } \\
\text { negatively affect its being implemented. }\end{array}$ & 2.43 & 0.65 & High & 2 \\
\hline 10 & $\begin{array}{l}\text { The teacher provides an effective educational } \\
\text { environment for the implementation of a course. }\end{array}$ & 2.46 & 0.64 & High & 4 \\
\hline 11 & $\begin{array}{l}\text { The teacher has various enhancement techniques for the } \\
\text { successful implementation of a course. }\end{array}$ & 2.35 & 0.71 & High & 6 \\
\hline 12 & $\begin{array}{l}\text { The ideal usage of technology in implementing a lesson } \\
\text { enriches it. }\end{array}$ & 2.14 & 0.70 & Moderate & 16 \\
\hline 13 & $\begin{array}{l}\text { The teacher doesn't care of the time allocated for } \\
\text { implementation of a lesson. }\end{array}$ & 2.25 & 0.69 & Moderate & 9 \\
\hline 14 & $\begin{array}{l}\text { The teacher uses a various set of learning resources to } \\
\text { enlarge the effective implementation of a course. }\end{array}$ & 2.25 & 0.70 & Moderate & 18 \\
\hline 15 & $\begin{array}{l}\text { The teacher necessarily distributes the time of a lecture } \\
\text { to the terms of the course. }\end{array}$ & 2.21 & 0.67 & Moderate & 11 \\
\hline 16 & $\begin{array}{l}\text { The teacher relates the topics included in a course to the } \\
\text { students' everyday-life skills. }\end{array}$ & 2.03 & 0.56 & Moderate & 17 \\
\hline 17 & $\begin{array}{l}\text { The teacher has teaching skills that draw the students to } \\
\text { learn. }\end{array}$ & 2.24 & 0.74 & Moderate & 14 \\
\hline 18 & $\begin{array}{l}\text { The teacher makes sure of the individual differences in } \\
\text { implementing a teaching course. }\end{array}$ & 2.19 & 0.66 & Moderate & 15 \\
\hline 19 & $\begin{array}{l}\text { The teacher chooses topics in a teaching course that } \\
\text { attract and motive the students to learn. }\end{array}$ & 2.40 & 0.74 & Moderate & 12 \\
\hline \multicolumn{2}{|c|}{ Total } & 2.26 & 0.60 & Moderate & - \\
\hline
\end{tabular}

Table (5) above illustrates that the total degree of the faculty members practicing their implementation role according to their students was moderate with a mean of $2.26(\mathrm{SD}=0.60)$. In fact, this finding would reflect that a 
faculty member's skill in university teaching implies in providing a suitable climate for implementing educational events, motivating his/her students and socially communicating with them. The highest statement was no. 2 "The teacher employs the terms and ideas belonging to a teaching course for effectively implementing the lesson" with a mean of 2.95 ( $\mathrm{SD}=0.81$ ). This kind of employment is certainly one of a faculty member's main tasks and responsibilities in terms of his/her implementation role, and the university students expect more of the same. This particular finding is somehow different from a related one in Suzanne \& Dale (1999) in that a university teacher cannot sort out his/her course's terms and often uses traditional teaching methods.

\section{Assessment}

Table (6): Means and SDs of the Faculty Members Practicing their Assessment Role

\begin{tabular}{|l|l|l|l|l|l|}
\hline Sr. & Statements & & & Moderate & 4 \\
\hline 1 & $\begin{array}{l}\text { The teacher makes sure of structural assessment } \\
\text { during the course's exercises. }\end{array}$ & 2.07 & 0.63 & Moder \\
\hline 2 & $\begin{array}{l}\text { The teacher follows up any feedback for addressing } \\
\text { the strengths and weaknesses in a teaching course. }\end{array}$ & 2.28 & 0.62 & High & 1 \\
\hline 3 & $\begin{array}{l}\text { The teacher applies personal assessment to choose } \\
\text { a suitable type of courses to the student. }\end{array}$ & 1.84 & 0.51 & Moderate & 5 \\
\hline 4 & $\begin{array}{l}\text { The teacher uses various strategies of assessment to } \\
\text { enrich a teaching course. }\end{array}$ & 2.00 & 0.59 & Moderate & 3 \\
\hline 5 & $\begin{array}{l}\text { The teacher employs indirect assessment to } \\
\text { enhance the status of a teaching course with the } \\
\text { students. }\end{array}$ & 2.05 & 0.57 & Moderate & 2 \\
\hline Total & 2.03 & 0.53 & Moderate & - \\
\hline
\end{tabular}

Table (6) above illustrates that the faculty members practicing their assessment role according to their students was moderate in total with a mean of $2.03(\mathrm{SD}=0.53$ ). This efficiency might require higher skills at all the professional sides of assessment. Furthermore, some faculty members had not received any education in assessment so that they would be able to consider the differences between their students. Hence, the students' satisfaction as to this aspect was moderate and the highest statement was no. 2 "The teacher follows up any feedback for addressing the strengths and weaknesses in a teaching course" with a mean of $2.28(\mathrm{SD}=0.06)$.

The students were concerned in the faculty members' role in following up their achievements, addressing the academic and managerial problems they would face and modifying their behaviors for avoiding the potential weaknesses and enhancing the strengths.

Third: For answering the third research question of the study (i.e. to what extent are the faculty members' conceptions of the three roles related to their teaching practices?), the correlation coefficients between the faculty members' conceptions of their role in selecting the aspects of courses and levels of practicality according to the students were computed. The results were as follows (see Table 7 below):

Table (7): Correlation of the Faculty Members Conceiving and Practicing their Roles in Planning, Implementation and Assessment

\begin{tabular}{|l|l|l|l|l|l|l|}
\hline \multirow{2}{*}{ Sr. } & \multirow{2}{*}{ Aspect } & \multicolumn{2}{|l|}{$\begin{array}{l}\text { Faculty members } \\
\text { conceiving their roles } \\
\text { from their own }\end{array}$} & $\begin{array}{l}\text { Faculty } \\
\text { practicing their roles } \\
\text { perspectives }\end{array}$ & $\begin{array}{l}\text { members } \\
\text { from the students' } \\
\text { perspectives }\end{array}$ & \\
\cline { 3 - 6 } & & Mean & SD & Mean & SD & \\
\hline 1 & Planning & 3.39 & 1.25 & 2.19 & 0.67 & 0,25 \\
\hline 2 & Implementation & 3.94 & 0.95 & 2.26 & 0.60 & 0,27 \\
\hline 3 & Assessment & 3.92 & 0.92 & 2.03 & 0.53 & 0,23 \\
\hline Total & & 3.75 & 1.04 & 2,20 & 0,60 & 0,33 \\
\hline
\end{tabular}

*Sig. at 0.05, **Sig. at 0.01 
It is obvious from Table (7) above that the correlation coefficients between the faculty members' conceptions of their roles in the planning, implementation and assessment of university courses on the one hand and their teaching practices of the same according to the students were all moderate and statistically significant at 0.01 or 0.05. In actual fact, this conclusion would reflect how largely compatible the two sides were found.

\section{Recommendations and suggestions}

In light of its results above, the study makes available the following recommendations and suggestions:

- Making use of the list of teaching practices as developed by the present study.

- Holding enrichment courses for university teachers to develop their performance in terms of planning.

- Making active the partnership between faculty members and their students for more energetic contents and practices.

- Conducting a descriptive survey to investigate the academic courses and teaching strategies needed by the university students in Jordan.

\section{References}

Arabiyat, B. M. (2007). Classroom Management and Educational Environment. Amman, Jordan: Culture House for Publishing and Distribution.

Ashoush, I. (2015). Consistency between mathematics teachers' convictions and practices on the playing-for-learning technique at the elementary grades. Mathematics Educational Journal, 18(7). 6-53.

Assaf, S. Al- (2012). An Introduction to Research in Behavioral Sciences. Riyadh, Saudi Arabia: Al Obeikan Bookstore.

Aswad, Z. Al- (2014) A university teacher's creative teaching practices and personal variables: A field survey on university teachers in Algeria. PhD Thesis in Education. Qasedi Merbah University. Faculty of Humanities.

Ballantyne, P. et al. (1999). Researching university teaching in Australia: Themes and issues in academics reflections. Studies in Higher Education, 24(2). 237-257.

Dosari, I. M. Al- (2009). A Framework of Educational Assessment. $2^{\text {nd }}$ Ed. Riyadh, Saudi Arabia: GCC Library of Education.

Doyle, W. (2008). Work in mathematics classes: The context of students thinking during instruction. Educational Psychologist, 23(2). 167-180.

Fahmi, M. S. (2011). Pedagogical Planning: Basics, Techniques and Problems. Cairo, Egypt: Anglo Egyptian Library.

Filmban, A. (2002). Development of a university teacher's performance: Problems and solutions. Symposium on University Teachers' Development November 1-2, 1999. King Saud Research Center. 255-284.

Ghafour, F. Abdul- (2002). Problems affecting a faculty member's performance at the College of Basic Education in Kuwait. Arab Gulf Journal, 85. 89-128.

Ghubeisi, M. I. (2010) Teaching, Planning, Implementing and Assessing Social Studies. Kuwait: Al Falah Bookstore Publishers.

Herman, J. (2003). Assessing new assessments: How do they measure up? Theory into Practice, 36(4). 196-201.

Jackson, R. (2009). Never work harder than your student. Association for Supervision and Curriculum Development (ASCD). Alexandria.

Khalili, K. Al- (1405AH). Some basics and Exercises in assessment for the first three grades. Resalat Al Mu'allim, 5(26). 19-25.

Mujeidil, A. (1999). Academic problems of the faculty members at Damascus University. Damascus University Journal, 5(3). 43-95.

Salam, F. Abul- (2005) An Introduction to Educational and Psychological Assessment. ${ }^{\text {nd }}$ Ed. Makkah, Saudi Arabia: Islamic Heritage Library.

Sulieman, M. \& Essa, Hana (2006). Teaching practices of science teachers and vocational programs. $7^{\text {th }}$ International Conference on the Teacher Preparation Institutes in the Arab World in April 2006, Vol. 2. Fayoum University. 437-461.

Suzanne, Y. and Dale, S. (1999). Profiles of effective college and university teachers. Journal of Higher Education. 671-687.

Tartouri, M., \& Qudhat, M. Al- (2006). New Teacher: A Teacher's Guide to Effective Classroom Management. Amman: Al Hamed Publishing House.

Qandil, Y. (2010) Teaching and Teacher's Preparation. Riyadh, Saudi Arabia: International Publishing House.

Zaitoun, H. (2004) Teaching Skills. Cairo, Egypt: Book World Publishers. 